\title{
Csata AdÉL
}

\section{A MAGYAR HÍRMONDÓ SZEREPE BENKŐ JÓZSEF LITERATÚRATÖRTÉNET-ÍRÓI TEVÉKENYSÉGÉBEN}

\author{
Kulcsszavak: Benkő József, August Ludwig Schlözer, Rát Mátyás, Magyar Hírmon- \\ dó, 18. századi sajtó, historia litteraria
}

Benkő József az első magyar nyelvủ hírlap, a pozsonyi Magyar Hírmondó tudósítójaként múködött 1780-1786 között. Ebben a hat esztendőben közel hetven cikket publikált a lap hasábjain, és elkészítette annak mutatótábláját is. Kutatásaink szempontjából különösen fontosak azok a cikkek, amelyek az irodalomtörténet-írással, tudománytörténet-írással kapcsolatosak, hiszen úgy látjuk, az első magyar nyelvú lap teremtett lehetőséget arra, hogy a középajtai literátor kezdeti elgondolásai honismereti kötete De re litteraria in Transsilvania címú fejezetének bővítésére vonatkozóan megvalósuljanak.

Benkő írásainak témakörét tekintve két nagy kategóriát állíthatunk fel: a historia litteraria-tárgyú cikkeket, ill. az egyéb kategóriába tartozó írásokat. Ez utóbbi kategória gazdasági, közigazgatási, igazságszolgáltatási, katonai, mezőgazdasági, egyházi vonatkozású híradásokat takar, ill. olyan közleményeket, amelyek kuriózumjelleggel bírtak. A historia litteraria kategóriájába illeszkedik minden olyan jellegú írás, amely a tudományos és kulturális életet érintette. Ilyenképpen beszélhetünk intézménytörténetről, könyvekről való híradásokról, pályázatokról és azok eredményeit ismertető publikációkról, az egyéni mûveltségre vonatkozó közleményekről, kutatóutakról való beszámolókról stb. Mielőtt azonban rátérnénk ezeknek az írásoknak a részletesebb bemutatására, szólnunk kell arról a kontextusról, amely az első magyar nyelvú újság megjelenéséhez vezetett.

\section{A MAGYAR HÍRMONDÓ INDULÁSA}

Rát Mátyás, a lap első szerkesztője így vall az Elöre való tudakozásban:

„Nintsen már Európában egygy országos Nemzet-is, a ki a maga Hazájában történő változások, a világnak viszontagságai, az elmés

* Csata Adél (1991), PhD, irodalomtörténész. E-mail: adelcsata05@gmail.com. 
embereknek hasznos vagy furtsa találmányjaik, a Túdósoknak munkáik, s több a' féle emlékezetes dolgok felől szólló Híreket, naponként, hetenként avagy hónaponként, az ő saját nyelvén nyomtattatott írásokban, tanúság és múlatság kedvéért ne olvasná. Sőt, nem tsak Európának, hanem még Ámérikának-is minden nevezetes Városiban írattatnak s nyomtattatnak e' féle hírlelö Levelek. - Tsak az egygy Magyar Nemzet vólt még eddig, sok egyéb fogyatkozásai mellett, ezen igen hasznos szerzeménynek híjjával. Melly híjánosság valamint magában igen betstelen, úgy következéseivel-is mondhatatlan kárára és szégyenére válik az Hazának. Ugyan-is ez a többi között az oka, hogy nem tsak az egyéb világgal, hanem saját Hazánkkal s Hazánkfiaival-is olly szertelen esméretlenségbe úgy élünk, mint a féreg a dióban; azt sem tudván, a mi körülöttünk történik, s minket leg-közelebbről illet”. ${ }^{1}$

A Tudakozás szerzője vázolja a magyar újságírás hátrányos helyzetét az európai és amerikai viszonyokkal szemben. Ebból kifolyólag utal a lap jelentőségére: a lap voltaképpen hiánypótló szerepú, s célja, hogy képet nyújtson a magyar viszonyokról. Az első szám 1780. január elsején jelent meg. A hírlap indulásától 1782 végéig a szerkesztői tisztet az evangélikus Rát Mátyás töltötte be. A szerkesztő életpályáját, tanulmányait, a hírlap múködésében betöltött szerepét Kókay György ismertette Könyv, sajtó és irodalom a felvilágosodás korában címú kötetében. A szerző különös jelentőséget tulajdonít Rát tanulmányainak, hiszen a lelkészi pályára készülő evangélikus ifjú a Bél Mátyás-féle államismereti iskola szellemében nevelkedett, majd Göttingenben folytatott stúdiumokat, ahol Kókay szerint betekintést nyert az August Ludwig Schlözer professzor által tartott újságolvasási szemináriumok elméletébe és gyakorlatába. A Schlözer professzor által tartott újságkollégiumok hasznát a sajtótörténész pontokba szedve ismerteti. Ezek szerint az államismeret jeles múvelője fontosnak tartotta az egyes hírek kontextualizálását, azaz olyan történelmi, földrajzi, politikai ismeretekkel való ellátását, amelyek révén az olvasó átfogó, átlátható képet kaphatott egy-egy eseményről. Szerette volna, ha diákjai meg tudják különböztetni a híreket a kommentároktól, elítélte a jelentéktelen eseményekről való hosszas híradásokat, s ráirányította a figyelmet arra, hogy az egyes közlemények óvatosan kezelendők, némelyik hitelessége megkérdőjelezhető. Harmadrészt úgy tekintett a lapokra, mint a müveltségszerzés eszközeire, amelyek révén még a későbbiekben hivatali funkciókat

1 Elöre való Tudakozás: Ha vallyon találkoznának-é elegendó számmal, Hazájokat és Nemzeteket igazán szeretö Magyar Hazafiak, a kik Magyar nyelven iratandó új Hirekre, vagy-is Hirmondó levelekre szert tenni kivánnának?, http://real-j.mtak.hu/1019/1/Magyar_hirmondo_1780. pdf [2018. 11. 17.] 
betöltő egyének is kompetensen tudnak hozzászólni bizonyos kérdésekhez. ${ }^{2}$ Kókay kitér a hírlap jelentőségére, amelyet a Tudósitások alapján összegez. Eszerint a kiadvány olyan hidat jelentett, amely biztosította az információk áramlását a magyar nyelvterületen, ugyanakkor közvetített a külföld felé is, cáfolva azokat a vádakat, amelyek a magyarságot ismeretlen népcsoportként, esetleg kedvezőtlen fényben tüntették fel. ${ }^{3}$ Nyilvánvaló, hogy az első magyar nyelvú hírlap jelentősrészt ugyanazt a célt szolgálta, mint a korabeli historia litterariák, hiszen a magyar kulturális, tudományos élet előmenetelét hivatott a szélesebb körü olvasóközönség elé tárni, ezúttal már anyanyelven, ugyanakkor a mindennapi élet eseményeinek, gyakorlati hasznú információk közlésének is teret engedett, $\mathrm{s}$ a vegyes tartalomnak köszönhetően biztosította az átmenetet az irodalmi folyóiratok felé.

A Magyar hirleló levelek eránt való Túdósitásban a szerkesztő tudatja, hogy a kiadás terve kedvező fogadtatásra talált, hiszen számos előfizető jelentkezett, olyanok is, akik több példányt igényeltek, mi több „sok érdemes Túdósok és tiszt-viselő Urak pedig, még azon fellyúl holmi emlékezetes dolgok és történetek felôl való túdósításokat-is önként ígérni méltóztattanak" ${ }^{4}$ Ezen érdemes tudósok közé számlálhatjuk Benkő Józsefet is, aki első cikkét a Hírmondó 1780. szeptember 2-i számában közölte. Abban a hatéves periódusban, amikor Benkő a Magyar Hírmondó tudósítójaként múködött, a szerkesztői tisztséget egymást követően hat személy töltötte be: Rát Mátyás a lap indulásától 1782 végéig; Mátyus Péter 1783 elejétől az év végéig; Révai Miklós 1783 végétől 1784 tavaszáig. Révait Barczafalvi Szabó Dávid követte, aki csupán két hónapig (1784. május eleje-június vége) volt a hírlap szerkesztője. Ôt Szacsvay Sándor váltotta fel 1784 júliusától 1786 májusáig. Szacsvay távozása után egy ideig újra Barczafalvi került a lap élére, majd Tállyai Dániel, Ungi Pál és Szűcs Márton, ám mivel Benkő Szacsvay távozása után nem küldött tudósításokat, a lap további szerkesztőiről nem szólunk. Benkő ezek közül hárommal, Ráttal, Révaival és Szacsvayval levélbeli kapcsolatban állott, de például a Ráttal való levélváltás nem is arra a periódusra datálható, amikor ez a lap szerkesztője volt. A Benkő-levelezés csupán két, Rát Mátyás által küldött levelet regisztrál 1785-ből és 1787-ből, egy Révainak küldöttet 1784-ből és egy Révaitól kapottat 1785-ből, ill. egyetlen Szacsvay Sándor által feladott, 1784-es levelet. A Magyar Hírmondó első szerkesztőjének 1785-ös leveléből csupán regesztát közöl a levelezést közreadó Szabó György és Tarnai Andor, de még ennek alapján is az látszik, hogy a levélváltás nem érintette a tudósítói

2 KóкAY György: Könyv, sajtó és irodalom a felvilágosodás korában. Akadémiai, Bp., 1983 (a továbbiakban KóKAY: Könyv, sajtó). 98-100.

3 Uo. 101-105.

4 A Magyar hirlelő levelek eránt való tudósitás. http://real-j.mtak.hu/1019/1/Magyar_ hirmondo_1780.pdf [2018.11.17.] 
tevékenységet. ${ }^{5} \mathrm{~A}$ későbbi, 1787 -es levélben a feladó a félbeszakadt levelezés megújítására tesz kísérletet, készülő munkáiról és terveiről tájékoztatja a címzettet és segítségét kéri.

Révai Miklós és Benkő József levelezését tekintve úgy látjuk, hogy a kapcsolatfelvétel kezdeményezője Benkő volt, aki 1784 februárjában lelkesen üdvözli a Hírmondó új szerkesztójét:

„Örvendeztetett engemet a méltó dícséretű Ráth Mátyás Úrnak nyelvünk gyalulása körül való mozdulatja; szeretnem kellett Mattus Úrnak ahozz köttetett folytatását, olly igen a mint féltem a Magyar hírlelő Leveleknek félbenn szakaszkodásoktól: most pedig már emelkedvén emelkedem, és csak nem Montgolfiér levegö szekerébe repdesek, örömmel szemlélvén a Magyar Újság Levelek író polcára olly véggel lett ülésedet, hogy hazai nyelvünknek tovább lett fejtegetésébenn, és ki szélesítésébenn izzadozz”. ${ }^{6}$

Ebben a néhány sorban Benkő lelkes szavai mellett utalás történik a Hírmondó szerkesztőinek megítélésére is. Eszerint a levélíró a Rát- és Révai-féle programmal elégedett, Mátyus Péter tevékenységével kevésbé. Mátyus egyéves szerkesztősége alatt a lap színvonala visszaesést mutatott; az új szerkesztő nem állt elő programmal, s csak a hírek száraz közlésére vállalkozott. Ebben az időszakban nem kaptak helyet a tudományos élet eseményeirôl való híradások, könyvismertetések sem igazán, mi több, a lap stílusát és nyelvét tekintve is alábbhagyott az elődökéhez képest, állapítja meg Kókay György, azt is hozzátéve, hogy a lap színvonalának hanyatlása egyenesen arányos volt az előfizetők számának csökkenésével: a kezdeti 500 előfizető száma 200-ra apadt. ${ }^{7}$ Ez arra késztette a kiadót, hogy anyagi haszna érdekében más szerkesztő után nézzen, s ezt pedig a kezdetben Rát Mátyás által is ajánlott Révai Miklósban találta meg. Révai Miklós szerkesztői munkásságát Czibula Katalin méltatta „Eröltetlek mind azon által szép magyarságodra” címú írásában. A tanulmány szerzője megállapítja, a szerkesztôk közül Révai volt az, aki leginkább irodalmi beállítottságú volt. ${ }^{8}$ Koncepciójának értelmében a jó újságíró feladata, hogy széles körű ismerete-

5 Benkő József Levelezése. Szerk. Szabó György-Tarnai Andor. Kiadta a Magyar Tudományos Akadémia Irodalomtudományi Intézete, Bp., 1988 (Magyarországi Tudósok Levelezése I.), (a továbbiakban BENkő: Levelezése). 249.

6 Uo. 216.

7 KóKАY György:A magyar sajtó története. I.1705-1848. Akadémiai,Bp.,1979 (a továbbiakban KóKAY: A magyar sajtó). 83.

8 Cziвula Katalin: „Eröltetlek mind azon által szép magyarságodra”. A Magyar Hírmondó Révai Miklós idejében = Historia litteraria a XVIII. században. Szerk. Csörsz Rumen IstvánHegedưs Béla-Tüskés Gábor. Universitas, Bp., 2006. 476-477. 
ket és tájékoztatást nyújtson, s cikkei révén hozzájáruljon a magyar nyelv műveléséhez. Amint kiderül, az ismeretterjesztés mellett a lap népmúvelői feladatokat is felvállalt, szépirodalmi alkotásokat adott közre, esetenként a szerkesztő kritikával illetett egy-egy múvet, s híradásait, szépírói talentumának köszönhetően, történetekké formálta. ${ }^{9}$ Révai ezen újításai közül Benkő a nyelvmúvelés terén tett erőfeszítéseit értékeli a levélben, s arra kéri, írjon bőven magáról. Meg kell jegyeznünk, hogy ez a levél az egyetlen, amelyben a levélíró tegeződő formulát használ, ami azért is érdekes, mert ismeretlenként szólítja meg Révait, noha korábban tett már lépéseket annak érdekében, hogy ismeretséget kössön vele. Benkő Rátot kérte fel, hogy ajánlja be Révainak, azonban amint a levélből kiderül, ez nem történt meg ismeretlen okok miatt. ${ }^{10}$ A levél hangnemét átható lelkesedés és tisztelet mellett tulajdonképpen a címzett iránti bizalom és barátság ajánlása is azonosítható, bizonyára ennek lehet tulajdonítani a tegeződést.

\section{BENKŐ JÓZSEF ÉS SZACSVAY SÁNDOR}

A Hírmondó első szerkesztőinek leveleivel szemben azonban Szacsvay Sándoré bemutatkozó jellegű. Rögtön szembeötlik a levél datálása, 1784 februárja. Ezt a dátumot Szabó György és Tarnai Andor Jakab Elek Szacsvay Sándor ${ }^{11}$ címú munkájából vette át, azonban Kókay György munkájában az áll, hogy az említett a szerkesztői feladatokat 1784 júliusától látta el. ${ }^{12}$ A levél első néhány sora is bizonytalanságra ad okot, hiszen a Hírmondó munkatársa így ír: „Én az elmult egész esztendőben oly nagy nyavallyák között írván a M. Hírmondót...”. ${ }^{13}$ Ezek szerint már 1783-ban is Szacsvay foglalkozott a lap szerkesztésével és összeállításával, erről azonban a sajtótörténet nem emlékezik meg. Felvetődik a kérdés, honnan adódik ez az ellentmondás. A levél egyes tartalmi elemei arra engednek következtetni, hogy Jakab Elek hibásan rögzítette a levél dátumát. Meglátásom alátámasztására néhány példát is hozok. A szerkesztő ebben a levélben köszöni meg Benkőnek a mutatótábla elkészítését, ill. elnézést kér amiatt, hogy a Hírmondó egyes számai nem jutottak el a címzetthez, s e hiányosság pótlása végett a levéllel együtt küldi az elmaradt anyagot. A későbbiekben a Fogarasi Pap Józsefről szóló munka kiadásáról esik szó, ám ezzel kapcsolatban a szerkesztő megvallja, hogy nem sikerült megegyeznie a nyomdász Paczkóval,

9 Uo. 482-493.

10 Benkő: Levelezése 216.

11 JА Ав Elek: Szacsvay Sándor. I. Figyelő 1882/11. sz. 164. (Itt kell megjegyeznünk, hogy később Jakab Elek Szacsvayt 1783-tól a lap társszerkesztójeként határozza meg. Uo. 171.)

12 KóKAY: A magyar sajtó 89.

13 Bеnкő: Levelezése 216. 
folytatásokban pedig nem akarja azt kiadni a Hírmondóban. Megígéri Benkőnek, hogy szükség esetén saját költségén jelenteti meg a munkát. A Fogarasiról szóló írás az a halotti oráció lehet, amelyet Benkő 1785-ben, a kolozsvári református kollégium nyomdájában jelentetett meg, egy halotti búcsúztatókat tartalmazó, Socrates redivivus címet viselő gyújteményes kötetben. ${ }^{14}$ Fogarasi Pap József 1784 decemberében halt meg, tehát a Szacsvay levele semmiképp nem íródhatott 1784 februárjában, mert akkor még élt Fogarasi, s Benkőnek nincs más, a marosvásárhelyi professzorról szóló munkája. Hozzá kell tennünk, hogy a Hírmondó hasábjain 1785-ben jelenik meg a Fogarasi haláláról való híradás. ${ }^{15}$ Ugyanebben a levélben esik szó Benkőnek az 1784es, Erdélyi oláh nemzet képe címú, a parasztfelkelést is tárgyaló munkájáról, amely kapcsán Szacsvay azt ajánlja a szerzőnek, hogy Bécsbe küldje cenzúrára a kötetet, ugyanis máshol esély sincs a kiadás jóváhagyására. Azt is felajánlja, hogy amennyiben nem akadna a kiadásra vállalkozó nyomdász, Benkő a pozsonyi Patzkó-múhelyben megjelentetheti azt, s a tiszteletpéldányok mellett az eladott kötetek árából is kedvező részesedést ígér. A levél azért sem íródhatott 1784 februárjában, mert a parasztfelkelés 1784 őszén teljesedett ki, Benkő pedig nem tudhatott komplex munkával jelentkezni ugyanezen év elején, amikor az események még csak kezdeti stádiumban voltak. A Hírmondó 1785-ös számaiban viszont elég sûrűn olvashatók híradások az események állásáról, ugyanakkor a szerkesztő a május 14-i számban ad hírt Benkő munkájának megjelenéséről. ${ }^{16}$ Összegezve elmondhatjuk, hogy Szacsvay levele olyan eseményeket rögzít, amelyekre csak hónapokkal később került sor. Ezek alapján úgy véljük, Jakab Elek elírta az évszámot, az 1785 helyett 1784-et tüntetett fel. Szacsvay pedig valóban írhatta 1785-ből, hogy már előző évben is foglalkozott a Hírmondó kiadásával. Azt kell mondanunk, hogy Benkő hủ maradt Szacsvayhoz, ugyanis annak távozása után már nem publikált a lapban, hanem az általa újonnan megindított $\mathrm{Ma}$ gyar Kurir tudósítója lett.

\section{HISTORIA LITTERARIA A HÍRMONDÓ HASÁBJAIN}

Benkő írásainak körülbelül fele Rát Mátyás szerkesztősége alatt jelent meg. Ezek jól illeszkedtek azokhoz az elvárásokhoz, amelyeket a szerkesztő így foglalt össze:

14 Benkő József: Oltso Értzeket Arannyá Változtato, Söt Fa Garasbol Leg-Híressebb Arannyat tsináló Erdélyi Magyar Álkimista, az az Tiszteletes és Fötudós Philosophiae Professor Fogarasi Pap József = Socrates redivious. Seu Imago Philosophi Vere Christiani, Qua Exhibeturv Clarissimus, Ac Divinii Ingenii Vir, Dominus Josephus Pap de Fogaras. Typ. Colleg. Reform., Claudiopoli, 1785.

15 Magyar Hírmondó, 1785. jan. 29. 8. lev., 62.

16 Magyar Hírmondó, 1785. máj. 14. 37. lev., 295-296. 
„az imitt amott észre vett természeti dolgokat, tapasztalásaikat, némellyvídékek és helységek eránt tett jegyzéseiket, a napkeleti és déli szomszédságainkból tudtokra lett történeteket, vagy az emberek élelmek és keresményjeknek meg-jobbíttathatása eránt való észbevételeket vagy Observatióikat (...) véle [Ráttal] közleni ne sajnálják" ${ }^{17}$

Ezenkívül külön szól a nyomdászokhoz, könyvkereskedőkhöz, felhívván a figyelmüket arra, hogy saját (anyagi) érdekük megismertetni az olvasókkal az újonnan megjelenő kiadványokat. Emellett a felsőoktatási intézmények (egyetemek, akadémiák) professzorait is megszólítja, arra kérve őket, hogy ismertessék az intézményeikben született disszertációkat. A továbbiakban elhalálozási és születési adatok, alkalmi eseményeken elhangzott beszédekről való híradások, tisztségbeli változásokat érintő írások, gazdasági, mezőgazdasági, kereskedelmi ügyekről szóló hírek, jeles, régi eseményekről való történetek közlését irányozza elő. Benkő publikációinak jellege a fentebbi kategóriák csaknem mindegyikét érinti, hiszen egyaránt tudósít az időjárási és mezőgazdasági viszonyokról, a termés milyenségéről, a gabonafélék áráról, régi dokumentumok előkerüléséről, kereskedelmi viszonyokról, újonnan megjelenő könyvekről stb. Meg kell jegyeznünk, hogy a tudományos élet hírei bizonyos esetekben a „Tudománybéli dolgok”, „Toldalékok” rovatokban szerepelnek, máshol valamilyen más hír alá sorolódnak be, ${ }^{18}$ ugyancsak más esetekben egyáltalán nem esik szó ezekről. A 6. levelet így indítja Rát: „Ma ne féljenek azok, a kik a könyvek felöl való tudósításokat nem kedvellik, hogy a féléket kelljen olvasniok,"19 esetenként pedig jó néhány lapszámból hiányoznak az ilyen jellegư információk. A 16. levélben a szerkesztő külön fel is hívja a figyelmet arra: „Ideje már egyszer, hogy Magyar Hírmondó a Tudományoknak folyamatjáról-is emlékezetet tégyen”. ${ }^{20} \mathrm{Az}$ egyes lapszámok tartalma jól láttatja, milyen információk birtokában volt éppen a szerkesztô, s azokban az esetekben, ahol a tudománybéli dolgok csak kis számban szerepeltek, valahová máshová sorolódtak be.

Benkő nevével az 1780-as lapszámok elé illesztett Elól-járó beszéd gyanánt való utól-irásban találkozunk, amelyben Rát Mátyás megfogalmazza, hogy eleget téve az olvasók kívánalmának, utólag közreadja a lap megindítása előtt megjelentetett Tuda-

17 A Magyar hirleló levelek eránt való Túdósitás 15. pontja

18 Például Rát Karl Windisch Geographie des Königreichs Ungarn címú kötetének megjelenéséről a Hazabéli dolgokról való híradások 5. pontjaként szól. (Vö. Magyar Hírmondó 1780. jan. 15., 5. lev., 32.) Az pedig, hogy Horányi Elek Memoria Hungarorum címú kötetéért dicséretet kapott a lipcsei tudóstársaságtól, újra csak egy pontja a Külömb-külömbféle történetek rovatának. (Vö. Magyar Hírmondó 1780. ápr. 29., 35. lev., 277.)

19 Magyar Hírmondó, 1780. jan. 19., 6. lev., 41.

20 Magyar Hírmondó, 1780. febr. 23., 16. lev., 128. 
kozást is. Az Elól-járó beszéd 1781 májusában kelt. A szerkesztő ebben a rövid bevezetőben utal arra, hogy a Hírmondó 1780-as mutatóját Benkő József készítette el. ${ }^{21}$ A középajtai pap első cikke az 1780. szeptember 2-i számban jelent meg, ám a lap olvasói számára nem volt ismeretlen, hiszen Rát már korábban informálta közönségét munkásságáról. Az 57. levélben éppen aktuális tevékenységéről közöl híradást: „Ama túdós és hazájának esmértetése körül jeles szorgalmatossággal forgolódó Erdélyi Edjházi Tanító, Benkö Jósef Uram, most Erdélynek tartományit járja, olly véggel, hogy a mint a Transsilvania nevü könyvébenn, melly Bétsbenn jött vala-ki, megígérte, naponként a Transsilvanica Flórát (az Erdélybenn termő füveknek megíratását) készíthesse”. ${ }^{22}$ Amellett, hogy Benkő növénytani kutatásairól szól a szerkesztő, a Transsilvania címú kötetnek kedvező recepciójáról is megemlékezik, megjegyezvén, hogy a göttingeni tudóstársaság kedvező bírálatot adott közre lapjában, a Göttingische Gelehrte Anzeigenben.

Amint említettük, Benkő 1780 szeptemberében közli első cikkét a Magyar Hírmondóban. Ebben tudósítja az olvasót az erdélyi sáskajárásról, Mária Terézia új rendeleteiről, majd a tudományt illető dolgokról is, hiszen ekkor számol be arról, hogy Szebenben könyvesbolt nyílt, ill. Martin Felmer Erdély történetét tárgyaló, Primae Lineae, M. Principatus Transylvaniae Historiam antiqui, medii et recentioris aevi exhibentes et illustrantes címú munkájának megjelenésérôl is informálja az olvasókat.

A következő, ugyanezen hónapban közölt híradás jóval bővebb, ám ez sem a tudományokat illető részben kap helyet, hanem a Magyar ritkaságoknak nevezett rovatban, a tartalom különlegessége miatt. A beszámoló Balog József botanikus tanulmányairól, Benkőnek ajánlott kötetéről és amerikai útjáról szól. Balog József nevével nem találkozunk a honismereti munka tudósnevei között, hiszen ennek megjelenésekor körülbelül 18-20 éves lehetett az említett, tehát még tanulóéveiben járt. Ennek ellenére a Hírmondóban közreadott tudósítás minden olyan információt tartalmaz, amelyek a tudósok kapcsán is említést érdemeltek (stúdiumok, külföldi oktatók nevei, peregrinációk), sőt, a hírlap lehetőséget adott a bővebb leírásra is. Az itt közreadott információk levélbeli kapcsolaton nyugszanak, hiszen Balog József 1779 júniusában küldi el a kötetében megjelenő, Benkőnek szánt ajánlást, köszönő sorait. Benkő 1780 februárjában tudósítja Balog Sándort fiának hogylétéről és hollétéről, ugyanakkor a levélben olyan információk is olvashatók, amelyek a cikkben is feltünnek. Ebben Benkő beszámol az említett tanulmányairól, az ôt oktató tanárokról és azok szerepéről az amerikai utat tekintve, amelyet rendkívüli eseményként láttat. Részletesen szól a hajóutról, az egyes földrajzi helyeket a schlözeri, Rát által is szorgalmazott kontextualizálás igényével írja le, ezáltal is segítve az olvasó térbeli eligazodását. Beszámol Balog betegségéről, felgyógyulásáról, a természettudományokat érintő kuta-

21 Elöl-járó beszéd gyanánt való utól-írás (2., számozatlan oldal)

22 Magyar Hírmondó, 1780. júl. 15., 57. lev., 464. 
tásairól. Említést tesz arról is, hogy az erdélyi utazó disszertációját neki, az erdélyi Benkő Józsefnek ajánlotta, akit nemrégiben felkért Mária Terézia botanikai órák megtartására. Ez a gesztus, saját maga nevének említése sem véletlen, hiszen mind a neki szánt ajánlással, mind a császárnő által felkínált lehetőséggel a mások általi megbecsülést is bemutatni hivatott, bizonyítva szakmai jártasságát e téren. Amint kiderül, sorozatban akarja továbbra is informálni az olvasókat Balog kutatásainak elörehaladásáról. A híradás végén valószínúleg a szerkesztő Rát párhuzamba állítja az Erdélyben és a Magyar Királyságban folyó botanikai kutatásokat, s óvatosan utal arra, hogy e téren az erdélyiek teljesítménye meghaladja a királyságbeliekét. ${ }^{23} \mathrm{Ez}$ a párhuzam mintegy ösztönzésként is értelmezhetô, amely a királyságbeli tudósok aktívabb múködését hivatott kezdeményezni, ugyanakkor azt is mondhatjuk, hogy a természettudományi kutatások terén egyfajta rangsorolás is történik. Ilyenképpen az erdélyi tudományos élet fejlődésének bemutatása nem csupán a külföld részéről érkező, elmaradottságot célzó vádak megdöntésére irányul, hanem a királyságbeli tudósoknak is példaként szolgálhat.

Biró Annamária Erdélyi jelenlét a nyugat-magyarországi sajtótermékekben. Johann Seivert és Benkó József tudósitói tevékenysége címú írásában a két erdélyi hírlaptudósító tevékenysége alapján azt vizsgálja, hogyan jelenik meg Erdély képe a nyugat-magyarországi sajtóban, érzékelhetôvé válnak-e ezekben a lokális specifikumok, konstituálódik-e egy koherensnek tekinthető régió. A kutatás tárgyául éppen a Magyar Hírmondóban, ill. az Ungrisches Magazinban közölt publikációk szolgálnak. Az ezekben megjelent híradások vizsgálata során a tanulmányszerző arra a következtetésre jut, hogy a régió történelmét tekintve nem rajzolódik ki egy egységes Erdélykép, hiszen Seivert szászként van jelen, esetében a szászok jogi, történelmi helyzetét érintő híradások vannak túlsúlyban, a székely Benkő esetében viszont gyakrabban olvashatunk Erdély más nemzeteit (szászokat, románokat) érintő tudósításokat. Ezt egyrészt a tudós hazafiság magatartásmódjával, másrészt a középajtai pap elfogulatlanságával magyarázza. Ha történelmében és privilégiumok tekintetében nem is állapítja meg Biró Annamária -, de a természeti viszonyok, anekdoták, tudományos eredmények felmutatása terén inkább megmutatkozik az erdélyi régió mint egységes kép, noha igaz, még ezekben az esetekben sem tekinthetők erősnek ezek a kontúrok, hiszen a tudósítók tevékenységükben sokkal inkább látták az új fórum nyújtotta, saját munkásságuk népszerüsítését elősegítő lehetőséget, mintsem hogy Erdélyről akartak volna közvetíteni valamilyen képet. ${ }^{24}$ Úgy látjuk, hogy a Balog József tevékenységéről való beszámoló éppen az erdélyi tudományosság és szakképzettség bemutatására

23 Magyar Hírmondó, 1780. szept. 9., 73. lev., 589-592.

24 Biró Annamária: Erdélyi jelenlét a nyugat-magyarországi sajtótermékekben. Johann Seivert és Benkő József tudósitoói tevékenysége. Acta Historiae Litterarum Hungaricarum 2018/34. sz. 11,14 . 
irányul, amelyeket Benkő a királyságbelieknek és a távolabb élőknek egyaránt szeretne bemutatni. Ez és a hasonló jellegü írások a historia litterariák hagyományát viszik tovább, amelynek legfontosabb mozgatóerói között ott találjuk a kulturálatlanság ellensúlyozására való törekvést, de a bizonyítási szándékot, a tudományos fejlődés bemutatásának igényét is.

A következőkben Benkő tollából a mezőgazdaságot, igazságszolgáltatást érintő híradások származnak, majd november végén figyelhetünk meg újabb, a tudományosságot érintő cikket, ekkor ugyanis saját gyújtőútjának tapasztalatait osztja meg az olvasóval. Ez az írás már az Erdélyi Tudománybéli Túdósitásokban kap helyet, s ez egy újabb példája annak, hogyan is épülnek egymásra a Hírmondóban publikált tudósítások. Az első részben a cikkszerző utal arra, hogy a lap egy korábbi számában már említést tett növénytani kutatóútjáról, minek folytán a botanikust többen is megszólították levélben, éppen ezért kötelességének érzi informálni az olvasókat kutatásának előrehaladásáról és a növénytani ismeretek elsajátítására létrehozott intézményekről. Ebben a tudósításban végül is az intézményekről nem olvashatunk, ám a kutatóutak leírása annál részletesebb. A szerkesztő idézőjelben adja közre Benkő levelét, ezáltal jelezve, hogy nem alakította azt sem tartalmi, sem szerkezeti szempontból. Ebben a levélben részletesen beszámol arról, milyen vidékeket, településeket járt be, milyen gyakorisággal, milyen nehézségekbe ütközött, ill. vall megjelentetni kívánt növénytani munkájáról. ${ }^{25} \mathrm{Meg}$ kell jegyeznünk, hogy a régió feltérképezése nem csupán botanikai téren hozott eredményeket, hiszen az utak során Benkő nem egyetlen tudományterületre összpontosította figyelmét. Ezeket az alkalmakat kihasználva gyújtött történeti dokumentumokat is. Egy lábjegyzetben részletesen számol be arról, hogyan jutott hozzá bizonyos iratokhoz másolás végett, megjegyezvén, hogy minderre a zernesti havasokban való növénytani kutatóútja végeztével került sor, ${ }^{26} \mathrm{~s}$ erre utal a szerkesztő egyik megjegyzése is 1781-ből. Rát így informálja az olvasókat: „Benkö Jósef Uram most ismétlen, Füvészés és Históriákra való írásoknak nyomozása, gyüjtése kedvéért, Erdélybenn széljel jár”. ${ }^{27}$ Úgy látjuk, hogy ez a párhuzamos érdeklődés a göttingai paradigma által propagált holisztikus látásmódnak egy újabb bizonyítéka.

A publikáció folytatása a lap következő számában olvasható. Ekkor számol be az erdélyi kertekről és azok jelentőségéről. Konkrétan a Brukenthal Sámuel feleki birtokán található üvegházat mutatja be, de emellett kitér könyvtárának gazdag állományára is, majd említést tesz a Teleki Sámuel által gyüjtött kötetekről, Koppi Károly könyvtáráról, ám ezek csak rövid kitérők, részletes bemutatást nem olvashatunk ró-

25 Magyar Hírmondó, 1780. nov. 25., 95. lev., 770.

26 Benkő József: Erdély. Ford. Szabó György. Székely Nemzeti Tanács-Tortoma Kiadó, Sepsiszentgyörgy-Barót, 2014 (a továbbiakban Benkő: Erdély). 341.

27 Magyar Hírmondó, 1781. júl. 14., 54. lev, 429. 
luk. Tény, hogy az írás gerincét a botanikai tematika alkotja, s itt tesz említést gr. Székely Ádám könyvadományáról, aki természettudományi tárgyú könyvekkel látta el a kolozsvári református kollégium könyvtárát. Az utolsó részben Balog József legutóbbi levelérôl számol be, ill. azon szándékáról, hogy növényeket, kitömött madarakat és halakat küldjön Erdélybe. ${ }^{28} \mathrm{~A}$ Balog kutatóútjával kapcsolatos tudósításokat csak részben sikerült megvalósítania, ugyanis az utazó levelei, ismeretlen okok miatt, nem értek el hozzá, s ebből kifolyólag csak találgatni tudta, mi is történhetett. Ezeket a kérdéseket, ill. az amerikai utazó halálhírére vonatkozó sejtelmeit tudja csak megosztani a hírlap olvasóival. Beszámol Molnár Ádám bukaresti orvos haláláról is. Akárcsak a lexikonok szócikkeiben, az olvasó tudomására hozza az említett születési helyét és idejét, szolgálati állomásait, ill. azt, hogy melyik külföldi tudóstársaságnak volt a tagja. ${ }^{29}$

A 18. századi historia litterariák sok esetben a res litteraria részeként a könyvtárak, nyomdák, iskolák történetét is tárgyalták. Benkő esetében az erdélyi könyvesházak leírását nem találjuk meg a honismereti munka alfejezeteként, de a Hírmondó hasábjain már igen, ahol két egymást követő számban ismerteti az olvasókkal a kollégiumi és magánkönyvtárakat. Ezek a Tudományt illetó dolgok cím alatt kapnak helyet. A szerkesztő visszacsatol egy korábbi számra, jelezve, hogy futólag már történt utalás az erdélyi könyvesházakra. A könyvtárak az ismeretek gyarapításának egyik lehetőségeként definiálódnak, de Rát kiemeli, hogy ezek a haza megismerése szempontjából is fontosak. Felsorolásszerủen tér ki a királyságbeli intézményi és egyéni könyvtárakra, a továbbiakban pedig egy erdélyi levelező "Jó-akaró” tudósítására alapozva ismerteti az erdélyi könyvtárakat. Elsőként az enyedi kollégium könyvtáráról szól. Említésre érdemesnek tartja a könyvtár folytonos bővülését, ill. azt is, hogy a magyarul íródott régebbi és újabb könyveknek „külön házuk van”.

A későbbiekben szól azokról, akik könyvgyüjtéssel foglalkoznak, s akikkel ő maga is személyes és/vagy levélbeli kapcsolatban állott. Konkrét példaként Szathmári Pap Mihályt, Kendeffy Ráhelt említhetjük. A továbbiakban a református és katolikus iskolák gyújteményeinek gyarapodására tér ki, ám azt nem vázolja, kiknek az adományai tették lehetôvé az egyes állományok számának megnövekedését. Rövid utalás történik a kolozsvári iskola felszereltségére, ahol konkrétan a természet kémleléséhez szükséges eszközök meglétét nyugtázza, majd újra a számára közelibb enyedi könyvtárra tér vissza, amelynek értékei között az ott található numizmatikai gyüjteményt is megemlíti, hozzátéve, hogy ilyennel rendelkezik Brukenthal Sámuel is. Az érmék gyüjtésének módját és néhány gyüjtőt is felsorol, ilyenképpen találkozunk Cornides Dániel, Seivert János vagy Koppi Károly nevével. A zárlatban Teleki József Marosvásárhelyen őrzött könyveire és kitömött állatokkal berendezett múzeumára tér ki,

28 Magyar Hírmondó, 1780. nov. 29., 96. lev., 776.

29 Magyar Hírmondó, 1781. jan. 6., 3. lev., 10-11. 
amely meglátása szerint egészen egyedinek tekinthető erdélyi viszonylatban. ${ }^{30}$ Azt mondhatjuk, hogy az itt közreadott információk teljes mértékben beépülhettek volna a honismereti munka intézménytörténetet tárgyaló részébe, azonban erre nem került sor. Mivel Benkő ezt a munkáját is bővíteni kívánta, nem kizárt, hogy a tervezett második kötetbe illesztette volna a könyvesházak bemutatását. A kéziratot sürgősen el kellett juttatnia a kiadóhoz, s valószínúleg nem is lett volna ideje egy ilyen alfejezet kidolgozására, hiszen láthattuk, a nyomdászatról szóló rész is elég rövid, $\mathrm{s}$ az is nagyrészt Bod Péter Erdélyi Féniks címú munkájának kivonata. Mindenesetre a megjelent cikkek hiánypótlásként is tekinthetôk, hiszen olyan terek rövid bemutatását tűzik ki célul, amelyek a múveltségszerzés lehetőségeiként voltak meghatározhatók, a res litterariához tartoztak, s láttatták azt is, hogy az erdélyi foúri és tudósréteg fogékony az újdonságra, a tudásra, az egzotikumok megismerésére. A következő számban kiegészítésként a brassói és szebeni evangélikus iskolák könyvtárairól olvashatunk, amelyeket többnyire az ezekben fellelhetô régi kiadványok miatt tart értékesnek a cikkszerző, megjegyezvén, hogy a brassói iskola állományának egy része megsemmisült egy túzvész során. ${ }^{31}$ Jól látható, hogy a stúdiumai során jobban megismert enyedi könyvtár bemutatása kapja a hangsúlyos szerepet, mások épp csak említést érdemelnek. A különféle múzeumok és gyüjtemények ismertetése újra arra enged következtetnünk, hogy Benkőt valóban az a széles körü érdeklődés jellemezte, mint a göttingai államismereti iskola tagjait, hiszen kitér az éremgyújteményekre, amelyet már diákkorában ismerhetett, de foglalkoztatták ôt a természettudományi kuriózumok is, mint Teleki József kitömött állatokkal berendezett múzeuma. Másrészt azt is bizonyítani kívánta, hogy Erdélyben is akadnak tudománypártoló főurak, akik gyüjteményei lehetőséget kínáltak a gyakorlati tudás megszerzésére is.

A következő hónapokban nem adott közre tudományos tevékenységet érintő írásokat, ekkor inkább mezőgazdasági, közigazgatási, igazságszolgáltatási ügyekkel, az időjárást érintő érdekességekkel tölti ki az erdélyi híradásokat. Közel egy év után, 1782 júniusában újabb írást olvashatunk tôle Fogarasi Pap József tevékenységére és újabb nyereményére vonatkozóan, ill. közli a hollandiai társaság újabb pályázatának kérdését is. ${ }^{32} \mathrm{~A}$ Rát Mátyás szerkesztősége alatt közölt historia litteraria-vonatkozású cikkek sorát az 1782 decemberében közreadott, a régi történetírók munkáinak összegyưjtésére irányuló kérés zárja, amelyet mondhatni Rát tolmácsol az olvasók felé. ${ }^{33}$ Azt mondhatjuk, hogy Rát szerkesztőségének végeztével lezárult Benkő legtermékenyebbnek mondható tudósítói periódusa, hiszen ebben a szakaszban adta hírül az

30 Magyar Hírmondó, 1781. febr. 21., 15. lev., 113-116.

31 Magyar Hírmondó, 1781. dec. 24., 16. lev., 121-124.

32 Magyar Hírmondó, 1782. jún. 29., 50. lev., 393-394.

33 Magyar Hírmondó, 1782. dec. 21., 99. lev., 792. 
erdélyi tudományos életre vonatkozó információinak zömét, s csaknem minden hónapban megjelentetett valamit Erdély viszonyaira vonatkozóan.

\section{BENKŐ TUDÓSÍTÓI TEVÉKENYSÉGE MÁTYUS, RÉVAI, BARCZAFALVI ÉS SZACSVAY SZERKESZTŐSÉGE IDEJÉN}

Fennebb már utaltunk arra, hogy Mátyus Péter szerkesztősége alatt a lap visszaesést mutatott, s ugyanilyen visszaesés volt tapasztalható Benkő publikációinak számát tekintve is. Írásainak megjelentetése nem mondható rendszeresnek, ill. a tudományos tárgyú cikkek száma csupán kettőre tehető. Ezek egyike a Kálnoki Antal életrajzát tárja az olvasók elé, a másik a Kendeffy Elek gyermekeinek múveltségére vonatkozik. A híradás a Consiliarius Sapiens elnevezésú halotti búcsúztató szövegén nyugszik. Ebben a híradásban jegyzi meg, hogy a természettudományok nemrégiben az enyedi kollégiumban is tananyaggá váltak, s nemsokára ennek kolozsvári bevezetésére is sor kerül, hiszen gr. Székely Ádám már könyveket is adományozott erre a célra. ${ }^{34} \mathrm{~A}$ Kendeffyekről szóló híradás esetében az egyéni műveltségre került a hangsúly, a tudás megszerzésének lehetőségeire, amelynek mintegy csatornája volt az enyedi minerológus professzor, Benkő Ferenc, sőt, maga Benkő József is, aki ifj. gróf Kendeffy Jánosnak személyesen is levelet ír, dicséri botanikai foglalatoskodásait, és felajánlja, hogy készülő növénytani munkáját neki dedikálja. A levél értelmében a botanikát Benkő fejlődő tudományterületként látja, ugyanakkor hozzáteszi, „de a’ sem jó vólna azonban, hogy ezzel a’Tudománnyal el lopjuk egyéb szükséges Tanúlásainknak idejét: mert a’ Tudományok merő azon egybekötődött Rókonságok”. ${ }^{35}$ Nem kétséges, hogy itt egyéni tapasztalatról is beszélhetünk, hiszen egyik levelében a stúdiumnak szentelt anyagi és időbeli korlátokra is kitért. ${ }^{36}$ Másrészt az idézett mondat, a tudományok összekapcsolódásának hangsúlyozása a göttingai szemléletmód egy újabb konkrét megnyilvánulásaként is értelmezhető. Bár Kendeffy Elek nevével találkozunk a tudóslexikon szócikkei között is, a Hírmondóban bővebben olvashatunk róla, hiszen itt nem csak a gróf, hanem az ôt követő generációk fogékonyságának és tudásszomjának hangsúlyozása is előtérbe kerül. A hírlapban közreadott megemlékezés tehát olyan információkat foglalt magában, amelyek egyszerre bővíthették volna a lexikont mind a tudományosság, mind a család genealógiai bemutatásának szempontjából, amelyek, amint láthatjuk, szorosan összefonódtak.

A Kálnoki Antalról közölt hosszabb híradás több szempontból is különleges. Egyrészt a szöveg részét képezte Benkő nagyszabású, de megvalósulatlan tervének,

34 Magyar Hírmondó, 1783. nov. 08., 88. lev., 701-704.

35 BENKő: Levelezése 180.

36 Uo. 29. 
miszerint közre kívánta adni az erdélyi nemesek, vitézek katalógusát. Benkő a historia litteraria praxisa alapján kívánta Erdély kiemelkedő katonáit lajstromba rendezni, s ez az összeállítás képezte volna Transylvania Militaris című munkáját. Szabó György úgy látja a kötet fordításának előszavában, hogy ez az egyetlen töredék, amely az utókor számára fennmaradt. ${ }^{37}$ Kutatásaink során a Hírmondóban közölt híradáson kívül semmilyen erre vonatkozó információt nem találtunk, sem Benkő egyéb munkáiban, sem levelezésében nem esik szó erről. A hírlap bevezető szövegében utalást találunk a tervezett kiadvány nyelvére vonatkozóan. Eszerint a publikáció az eredeti, latin nyelven íródott szöveg kivonata és fordítása. ${ }^{38}$ Meglátásunk szerint az erdélyi és magyarországi vitézek lajstromának célja az olyan katonai pályát befutott egyének életpályájának részletesebb bemutatása lett volna, akik nem lévén mecénások vagy tollforgatók, nem kaphattak helyet az eruditusok névsorában. A Kálnoki család egyes tagjainak irodalmi tevékenységével Papp Kinga foglalkozott Tollforgató Kálnokiak. Családi íráshasználat a 17-18. századi Erdélyben című munkájában. Ebben Kálnoki Antal nevével is találkozunk. Érdemes megjegyeznünk, hogy a katonáskodó nemes életrajzi adataira vonatkozóan Papp Kinga Benkőnek a Hírmondóban megjelent cikkére alapoz, amelyben a bemutatás a háromszéki nemes katonai pályán való felemelkedésére esik. ${ }^{39} \mathrm{~A}$ család íráshabitusát vizsgáló kolozsvári kutató Kálnoki Antal esetében a levelezést veszi alapul, hiszen más jellegú irodalmi produktum nem maradt fenn utána, így teljesen érthetô, miért nem kaphatott helyet Benkő tudóslistájában. A hírlapban közölt, terjedelmesnek mondható írás jelentősége tehát nem elmarasztalandó, hiszen amellett, hogy a tervezett vitézi lexikon egyetlen fennmaradt nyomát láthatjuk benne, azt is elmondhatjuk, hogy az itt közreadott információk referenciaértékűek, hiszen ezekre még egy 21. századi kutató is támaszkodhat Kálnoki Antal katonai pályafutásának vizsgálatakor.

Révai Miklós és Barczafalvi Szabó Dávid szerkesztői periódusa alatt a Benkő által közreadott írások száma tíz alatt marad, a literatúratörténet kategóriájába ezekből is csak néhány illeszthető, amelyek egyrészt könyvmegjelenésre, másrészt pályadíj elnyerésére vonatkoznak.

Szacsvay idején jóval nagyobb számúak Benkő publikációi. Rögtön az elsőben olvashatunk II. József német nyelvrendeletéről, amelyről Benkő objektíven szól, csupán a rendelkezés ismertetésére vállalkozik; oktatásügyi reformtervezetekről, Szathmári Pap Mihály pályadíjáról, könyvek megjelenéséről (Teleki Sámuel Janus Pannonius-kiadása, Kovásznai Sándor latin versei). Ezt követően híradást olvashatunk Fogarasi Pap József tanári kinevezéséről és az ágostai vallásúak tübingai pereg-

37 BEnkő: Erdély 36. (Szabó György előszava)

38 Magyar Hírmondó, 1783. aug. 9., 62. lev., 489.

39 PAPP Kinga: Tollforgató Kálnokiak. Családi íráshasználat a 17-18. századi Erdélyben. EME, Kvár, 2015 (Erdélyi Tudományos Füzetek 284). 156-157. 
rinációjáról, az ezt követő számban pedig a vármegyék új felosztásának megfelelően bejelenti a Nova Transsilvania megjelenését, amely tulajdonképpen Benkő honismereti munkájának újabb változata lett volna. Újabb középajtai tudósítás olvasható a Hírmondó 1785. áprilisi számában, ekkor professzori kinevezésekről, ill. iskolai használatra kiadott könyv megjelenéséről informálja olvasóit. Az augusztus végi számban a tudós asszonyoknak is helyet szentel, itt olvashatunk Daniel Polixéna leányának múveltségéről. A híradást a nemesasszony halála generálhatta, ám ennek kapcsán Benkő kitér az érintett nyelvismeretére is. Úgy véli, hogy anyanyelvi szinten beszélt és írt franciául, értette a latint, és jártas volt több tudományterületen. Ezt követően, mintegy kuriózumként, beszámol a Bánffy György bonchidai kertjében kivirágzott aloéfáról. December végén tömbben adja közre a május és november közötti periódus híreit, szól az időjárási viszonyokról, árvizekről, termésekről, halálesetről, ill. a Benkőt is foglalkoztató Haller Gábor-féle naplóról..$^{40}$ Utolsó cikke 1786 márciusában jelent meg, ebben könyvek kiadásáról, professzori kinevezésekről tudósít. Alig két hónap után, 1786 májusában Szacsvay távozik a lap szerkesztőségétől, s vele együtt Benkő is, akivel viszont a Szacsvay alapította Magyar Kurir tudósítójaként találkozunk újra. Benkő Magyar Kurirban közölt tudósításainak vizsgálata szétfeszítené e tanulmány kereteit, ezért ettôl eltekintünk. Eddigi vizsgálati eredményeink azonban jól mutatják, hogy Benkő írásai teljesen illeszkedtek a pozsonyi Magyar Hírmondó koncepciójába, sőt időnként a hírek kontextualizálásának szándéka is tetten érhető volt, így az August Ludwig Schlözer által kezdeményezett, Rát Mátyás által folytatott koncepció a középajtai pap szemléletében is testet öltött.

\section{THE ROLE OF MAGYAR HÍRMONDÓ MAGAZINE IN THE LITERARY HISTORIAN ACTIVITY OF JÓZSEF BENKÓ}

\section{Keywords: József Benkö, Schlözer August Ludwig, Mátyás Rát, Magyar Hírmondó, $18^{\text {th }}$ century press, historia litteraria}

The study presents the correspondent activity of József Benkô that he carried out in the journal Magyar Hírmondó. We examined the topic of his writings in the magazine and tried to show whether or not these publications were related to his activity as a literary historian. In addition to this, we tried to show whether his writings contributed to the development of the concept of publishing a new volume that would have included information on the cultural life of Transylvania. The results of our research show clearly that half of the published writings present the careers of scientists, the history of scientific institutions, the detail of research trips, etc., so these publications fall within the conception of literary history. Benkő, although he could not write a new volume, through the character and theme of these articles he developed his chapter De re literaria in Transsilvania of his work published in 1778.

40 Magyar Hírmondó, 1785. dec. 17., 99. lev., 801. 


\section{ROLUL REVISTEI MAGYAR HÍRMONDÓ ÎN ACTIVITATEA DE ISTORIC LITERAR A LUI JÓZSEF BENKÓ}

\section{Cuvinte-cheie: József Benkő, Schlözer August Ludwig, Mátyás Rát, Magyar Hírmondó, presa secolului al 18-lea, historia litteraria}

Studiul de față prezintă activitatea de corespondent a lui József Benkő pe care a exercitato în cadrul revistei Magyar Hírmondó. Am examinat tematica scrierilor sale apărute în revistă și am încercat să arătăm dacă aceste publicații au fost legate sau nu de activitatea lui de istoric literar și de dezvoltarea concepției de a edita un nou volum care ar fi cuprins informații referitoare la viața culturală a Transilvaniei. Rezultatele cercetărilor noastre arată clar că jumătate din scrierile publicate prezintă cariere de savanți, istoria instituțiilor științifice, detalierea deplasărilor cu scop de cercetare etc., deci aceste publicații se încadrează în concepția historiei litteraria. Benkő, cu toate că nu a reușit să întocmească un nou volum, prin caracterul și tematica acestor articole și-a dezvoltat capitolul De re litteraria in Transsilvania al operei sale apărute în 1778. 